\title{
Detection of Nano $\mathrm{Eu}_{2} \mathrm{O}_{3}$ in Cells and Study of its Biological Effects
}

\author{
Yingqi Li ${ }^{1,2}$,Zhuoyu Li ${ }^{*}$, Xueping Zhou ${ }^{2}$, Pin Yang2* \\ ${ }^{1}$ Chemistry and Chemical Engineering College of Shanxi University, Taiyuan 030006, China ${ }^{2}$ Institute of Molecular Science, Shanxi \\ University, Key Laboratory of Chemical Biology and Molecular Engineering of Ministry of Education, Taiyuan 030006, China ${ }^{3}$ Institute \\ of Biotechnology, Key Laboratory of Chemical Biology and Molecular Engineering of Ministry of Education, Taiyuan 030006, China \\ *Corresponding authors. Email: $\underline{\text { lzy@ @xu.edu.cn }}$ or yangpin@sxu.edu.cn
}

\begin{abstract}
The biological effect of rare earth represents the dual natures of promoting cell proliferation and apoptosis. The research on the biological effect of rare earth compound has aroused wide concerns, but it remained unknown for the transmembrane and distribution under the action of rare earth oxide nanoparticle with cell as well as its biological effects. In the present data, it was firstly observed that the nano $\mathrm{Eu}_{2} \mathrm{O}_{3}$ entered the living $\mathrm{HeLa}$ cell by endocytosis using Laser Scanning Confocal Microscope. The distribution of nano $\mathrm{Eu}_{2} \mathrm{O}_{3}$ was in the cytoplasm around the nucleus. Moreover, we studied the effect of nano $\mathrm{Eu}_{2} \mathrm{O}_{3}$ on living cells under the condition of in vitro culture. The result showed that within the low concentration range $(<1.0 \mathrm{mg} / \mathrm{mL})$, the nano $\mathrm{Eu}_{2} \mathrm{O}_{3}$ had no obvious effects on the apoptosis and the cell cycle, although the morphology appeared changes. When the concentration gradually rose, it had dramatic biological effects. $1.0 \mathrm{mg} / \mathrm{mL}$ nano $\mathrm{Eu}_{2} \mathrm{O}_{3}$ caused the cellular damages and led to the vacuolation on the cell surface. Meanwhile, it obviously promoted the apoptosis of Hela cells, which suggested that $1.0 \mathrm{mg} / \mathrm{mL}$ nano $\mathrm{Eu}_{2} \mathrm{O}_{3}$ induced a necrotic cell reaction with respect to the nature of cytotoxin.
\end{abstract}

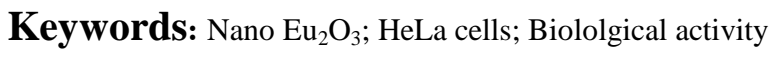

Citation: Y. Li, et al. Detection of nano $\mathrm{Eu}_{2} \mathrm{O}_{3}$ in cells and study of its biological effects. Nano Biomed Eng. 2010, 2(1), 24-30. DOI: 10.5101/nbe.v2i1.p24-30

\section{Introduction}

China is rich in rare earth resources and application, and rare earth mining, smilting, preparation and application are also growing andwidespread. Rare earth is a non-life element, while our country has widely applied rare earth to agriculture and stock breeding, and even medicine, making rare earth increasingly enter the environment, food chain, and human body. Therefore, the research on human security to rare earth, i.e. physiology, toxicity, and pharmacology, has aroused wide concern from many aspects [1-5]. In recent years, nanotechnology has been applied to every field in biology and medicine [6-10]. However, there are few reports about the activity and effect of the nano materials of the rare earth oxide in biological medicine.

The biological security is always an important factor in inhibiting the development of nano science and technology. Firstly, we should focus on the security evaluation to the people engaged in the rare earth extraction, smelting and application, i.e. the effect of rare earth and its compound dust to the practitioners' security, do these dusts enter the practitioners' body, and if they do, what kind of effect do they cause in physiology and toxicity. Secondly, does the rare earth nanoparticle have medical value? And what function and effect does it have to the survival, growth, metabolism, and apoptosis of the normal and cancer cell. These are obvious questions need to be solved.

$\mathrm{Eu}_{2} \mathrm{O}_{3}$ is a kind of material with red fluorescence, and there has been already the report about the nano $\mathrm{Eu}_{2} \mathrm{O}_{3}$ material [11], but no report about the research on its biological effects on cell. For example, whether the nano $\mathrm{Eu}_{2} \mathrm{O}_{3}$ can enter cell like other nano materials, and where is it distributed after entering cell? How about the toxicity to cell? In this paper, we evaluate the effect of nano $\mathrm{Eu}_{2} \mathrm{O}_{3}$ on cell morphology and viability. The result showed that the low nano $\mathrm{Eu}_{2} \mathrm{O}_{3}$ concentration $(<1.0 \mathrm{mg} / \mathrm{mL})$ has less biological effects, while the relative high-concentration $(\geq 1.0 \mathrm{mg} / \mathrm{mL})$ has obvious toxic effects to the cell. 
The nano $\mathrm{Eu}_{2} \mathrm{O}_{3}$ entered cells through endocytosis and localized just out the nuclear membrane. Finally, we studied the nature of cytotoxic reaction caused by 1.0 $\mathrm{mg} / \mathrm{mL}$ nano $\mathrm{Eu}_{2} \mathrm{O}_{3}$ with respect to apoptotic or necrotic features.

\section{Materials and Methods}

\subsection{Materials and instruments}

$\mathrm{Eu}_{2} \mathrm{O}_{3}$ with the granularity of $60 \mathrm{~nm}$ (purity $99.91 \%)$ was from Beijing Nachen Technology Development Co., Ltd). HeLa cell was provided by the Gene Engineering Center of Shanxi University. DMEM cell culture medium were purchased from Thermo Fisher Biological and Chemical Product Beijing Co., Ltd). The other materials used in this experiments listed as following: calf serum (Hangzhou Sijiqing Biological Engineering Materials Co., Ltd), Trypsin (Sino-American Biotechnology Company), EDTA (Solarbio), PI (Sigma), RNase (Sigma), Triton X-100 (Sigma), 4 \% paraformaldehyde (Solarbio), DIO (Beyotime Reagent), water-jacketed $\mathrm{CO}_{2}$ cell incubator (Shanghai Lishen Scientific Instruments Co., Ltd), FQ100DE numerical control ultrasonic wave washing machine (Kunshan Ultrasonic Instrument Co., Ltd), Laser Scanning Confocal Microscope (Olympus Fluoview FV1000), full automatic microplate reader (Bio-Rad Model 550), and fluorescence microscope (Olympus IX71)

\subsection{Cell culture}

Put the HeLa cells into the DMEM culture solution containing $10 \%$ fetal calf serum, $37{ }^{\circ} \mathrm{C}, 5 \% \mathrm{CO}_{2}$, and cultivate in the saturated humidity incubator. The cells pass one generation every two days after monolayer growth, and take the cells in the exponential phase of growth for use in the experiments.

\subsection{Transmembrane of $\mathrm{Nano} \mathrm{Eu}_{2} \mathrm{O}_{3}$ to HeLa cell}

$2 \times 10^{5} \mathrm{HeLa}$ cells seeded into the $35 \mathrm{~mm}$ culture dish with the cover glass on the bottom. The cells were grown at $37{ }^{\circ} \mathrm{C}, 5 \% \quad \mathrm{CO}_{2}$. After $16 \mathrm{~h}$, culture medium was replaced by culture solution containing the nano $\mathrm{Eu}_{2} \mathrm{O}_{3}$ after the ultrasonic shocking for $1.0 \mathrm{~h}$. And the cells were incubated for $7 \mathrm{~h}$. In the time, culture dishes were washed once with cold PBS and fixed with the $4 \%$ paraformaldehyde for 8 minutes.

For the images shown in Figure 1. The nucleus and cell membrane were labeled with $\mathrm{H} 33258$ and green fluorescence indicator DIO, repectively. Fluorescence images were obtained using a Laser Scanning Confocal Microscope (Olympus Fluoview FV1000).

\subsection{Cell viability measurement}

$5 \times 10^{3}$ healthy HeLa cells were plated into 96-well microtiter plates (Nunc). After $12 \mathrm{~h}$, culture medium was replaced by $100 \mu \mathrm{L}$ medium containing $0,50,200$ and $400 \mu \mathrm{g} / \mathrm{mL}$ of nano $\mathrm{Eu}_{2} \mathrm{O}_{3}$, respectively. The cells were then incubated for 7, 24, 48 and $72 \mathrm{~h}$. When the time was up, nano $\mathrm{Eu}_{2} \mathrm{O}_{3}$ solutions were aspirated and replaced by $180 \mu \mathrm{L}$ DMEM. $20 \mu \mathrm{L}$ MTT solution (5 $\mathrm{mg} / \mathrm{mL}$ ) were added into each well reaching a final concentration of $0.5 \mathrm{mg} / \mathrm{mL}$ MTT. After $4 \mathrm{~h}$ unreacted dye was removed by aspiration, the insoluble formazan crystals were dissolved in $200 \mu$ l dimethylsulfoxide (DMSO)/well with shaking for 10 minutes and measured spectrophotometrically in an ELISA reader at a wavelength of $490 \mathrm{~nm}$. Each group has 6 samples, and the data obtained from two independent experiments. The spectrophotometer was calibrated to zero absorbance using culture medium without cells. The relative cell viability $(\%)$ related to control wells was calculated by $\left[\mathrm{A}_{490}\right]$ sample / $\left[\mathrm{A}_{490}\right]$ control as the following formula:

Cell viability $=\left[\mathrm{A}_{490}\right.$ (sample) $/ \mathrm{A}_{490}$ (control) $] \times$ $100 \%$

Where $\mathrm{A}_{490}$ (sample) indicated the absorbency value by using $\mathrm{Eu}_{2} \mathrm{O}_{3}$ to treat cells, and $\mathrm{A}_{490}$ (control) indicated the absorbency value by using DMEM only containing $10 \%$ FBS to treat cells.

\subsection{Cell morphologic observation}

Cells $\left(1.5 \times 10^{5}\right)$ were seeded in a $35 \mathrm{~mm}$ petri dish and treated with media alone or with of 200, 400, 800, and $1000 \mu \mathrm{g} / \mathrm{mL} \mathrm{Eu}_{2} \mathrm{O}_{3}$ for 7, 24, $28 \mathrm{~h}$ respectively Following treatment, representative images were taken with the laser scanning confocal microscope and 40x objective.

\subsection{Appotosis (AnnexinV/PI assay)}

To evaluate whether cell death induced by the $\mathrm{Eu}_{2} \mathrm{O}_{3}$ has apoptotic or necrotic features, $4 \times 10^{5} \mathrm{HeLa}$ cells were seeded in a $60 \mathrm{~mm}$ Petri dish and treated with 200 $\mu \mathrm{g} / \mathrm{mL} \mathrm{Eu}_{2} \mathrm{O}_{3}$ for $7,24,48$, and $72 \mathrm{~h}$, respectively. Following treatment, cells were washed three times with cold PBS, and detached with trypsin-EDTA. The collected cells were applied to the apoptotic analysis with the Annexin V/PI cell apoptotic detection kit. The procedure followed the standard instruction and the cell suspension was subsequently analyzed by flow cytometry.

\subsection{Cell cycle analysis by FACS}

Cell cycle analysis and quantification of apoptosis was carried out by flow cytometry. Cells were seeded in $60 \mathrm{~mm}$ tissue culture dishes $\left(2.0 \times 10^{5}\right.$ cells/dish $)$, allowed to attach overnight, and treated for $72 \mathrm{~h}$ with $200 \mu \mathrm{g} / \mathrm{mL} \mathrm{Eu}_{2} \mathrm{O}_{3}$. At the end of the incubation period, detached cells were collected in $15 \mathrm{~mL}$ polypropylene centrifuge tubes along with the medium; culture dishes were washed once with PBS, adherent cells scraped off and combined in the same tube. After centrifugation (1000 rpm, $5 \mathrm{~min}$ ) cells were fixed (ice-cold $70 \%$ ethanol for $48 \mathrm{~h}$ ) followed by incubation in a 500 $\mu \mathrm{Lmixture}$ with $50 \mu \mathrm{g} / \mathrm{mL}$ of propidium iodide, 10 
$\mu \mathrm{g} / \mathrm{mL}$ of RNase and $1 \%$ Triton $\mathrm{X}-100$ for $20 \mathrm{~min}$ at room temperature in the dark. Flow cytometric analysis was performed on FACScan. Ten thousand cells were analyzed for each sample.

\section{Results}

As an initial approach to evaluation of biological effects of nano $\mathrm{Eu}_{2} \mathrm{O}_{3}$, cell transmembrane experiment was carried out cells incubated with nano $\mathrm{Eu}_{2} \mathrm{O}_{3}$. It has been known that the nano $\mathrm{Eu}_{2} \mathrm{O}_{3}$ can be excited at 543 $\mathrm{nm}$ by preliminary experiments, thereby nano $\mathrm{Eu}_{2} \mathrm{O}_{3}$ is the measurable particle with the red fluorescence. In order to know whether the nano $\mathrm{Eu}_{2} \mathrm{O}_{3}$ particle can enter the living cells by endocytosis, we use the Laser Scanning Confocal Microscope to record the images of the distribution of nano $\mathrm{Eu}_{2} \mathrm{O}_{3}$ in the cells at different positions on Axle Z. Figure 1A (a) and 1A (c) indicated the localization of the particles of nano $\mathrm{Eu}_{2} \mathrm{O}_{3}$ in $\mathrm{HeLa}$ cells with red fluorescence excited by the $543 \mathrm{~nm} \mathrm{He}$ $\mathrm{Ne}$ laser. These two imagines implicated the relative position of nano $\mathrm{Eu}_{2} \mathrm{O}_{3}$ in the intact cells with $\times 40$ object lens. Figure 1A (b) showed the nucleus with blue colour obtained by the $405 \mathrm{~nm}$ excitation and stained with $\mathrm{H} 33258$. Image 1A (d) is the merge of (b) and (c). It clearly indicated the nano $\mathrm{Eu}_{2} \mathrm{O}_{3}$ is round the nucleus, but can not enter it.

In order to further confirm that the nano $\mathrm{Eu}_{2} \mathrm{O}_{3}$ is in the cytoplasm, rather than the nucleus, we further stained the cell membrane with the green fluorescence indicator DIO, as figure $1 \mathrm{~B}$ shows. Figure $1 \mathrm{~B}(\mathrm{~h})$ is the cells in the control group and the cell membrane was labeled with the green fluorescence. After treating the cells with the $400 \mu \mathrm{g} / \mathrm{mL}$ nano $\mathrm{Eu}_{2} \mathrm{O}_{3}$, Figure $1 \mathrm{~B}(\mathrm{e}, \mathrm{f}$ ) showed green fluorescence DIO for the cell membrane and red fluorescence for the particles of nano $\mathrm{Eu}_{2} \mathrm{O}_{3}$. Figure $1 \mathrm{~B}(\mathrm{~g})$ is the merge of $1 \mathrm{~B}(\mathrm{e})$ and $(\mathrm{f})$. The imagines clearly indicated that the nano $\mathrm{Eu}_{2} \mathrm{O}_{3}$ particles with red fluorescence are in the cytoplasm range packed by the green cell membrane, and the red $\mathrm{Eu}_{2} \mathrm{O}_{3}$ particles are mainly distributed on the nucleolus surface, but can not enter the nucleolus. Hence, the experiments showed that nano $\mathrm{Eu}_{2} \mathrm{O}_{3}$ can certainly enter the living cells through endocytosis.

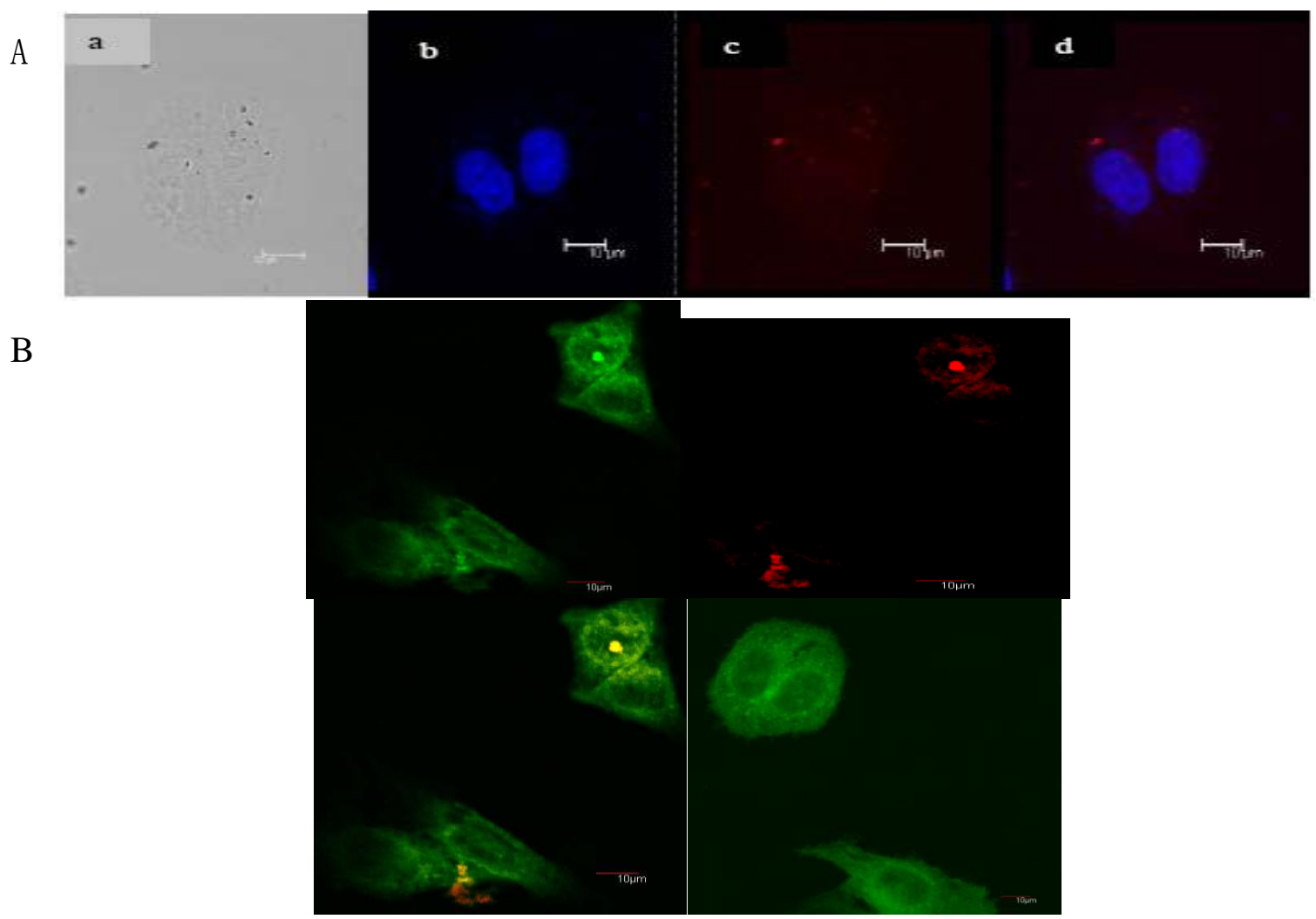

Figure 1. Distribution of the nano $\mathrm{Eu}_{2} \mathrm{O}_{3}$ in cells. A, (a) the imagine with bright field ; (b) the nucleolus stained with $\mathrm{H}-33258$; (c) the nano $\mathrm{Eu}_{2} \mathrm{O}_{3}$ particles with red fluorescence; (d) the merge of b and c. B, (e) the cell membrane dyed with green fluorescence DIO; (f) the nano $\mathrm{Eu}_{2} \mathrm{O}_{3}$ with red fluorescence; $(\mathrm{g})$ the merge of e and f; (h) the control group. Bar, $10 \mu \mathrm{m}$. 
To determine effects of nano $\mathrm{Eu}_{2} \mathrm{O}_{3}$ on cell viability, the MTT test was used. After incubating the cells with the nano $\mathrm{Eu}_{2} \mathrm{O}_{3}$ at the concentration of $50-400 \mu \mathrm{g} / \mathrm{mL}$ for $24 \mathrm{~h}$, the cell activity almost did not vary (figure $2 \mathrm{~A})$. In order to further confirm the effects of the lowconcentration nano $\mathrm{Eu}_{2} \mathrm{O}_{3}$ on the cell growth at different time, cells were incubated with $200 \mu \mathrm{g} / \mathrm{mL}$ nano $\mathrm{Eu}_{2} \mathrm{O}_{3}$ for 7, 24, 48, and $72 \mathrm{~h}$, respectively. The result as figure $2 \mathrm{~B}$ showed. The data indicated that after incubating cells with $\mathrm{Eu}_{2} \mathrm{O}_{3}$ for $48 \mathrm{~h}$, the cell viability did not change in comparison with control cells. When the treating time reached $72 \mathrm{~h}$, the cell activity showed slight decreasing trend, and the cell activity decreased by about $16 \%$ at $72 \mathrm{~h}$. The experiment results implicated that there was no obvious effects on the cell activity in the selected $\mathrm{Eu}_{2} \mathrm{O}_{3}$ concentration range and time.
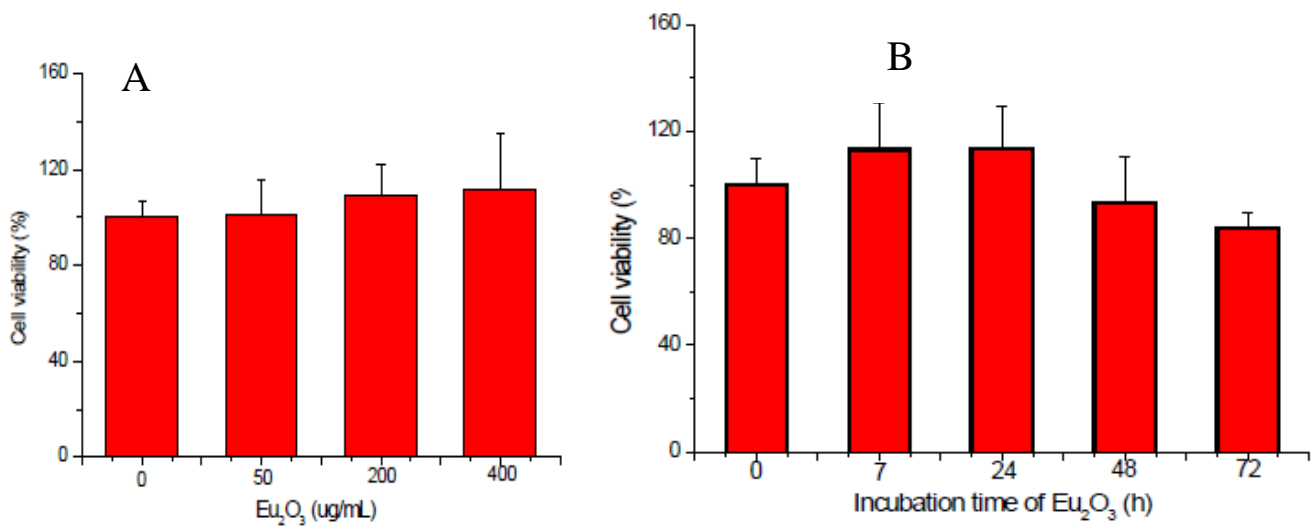

Figure 2. The effect of the nano $\mathrm{Eu}_{2} \mathrm{O}_{3}$ on the cell viability by MTT assay. (A) HeLa cells treated with different concentration of $\mathrm{Eu}_{2} \mathrm{O}_{3}$ for $24 \mathrm{~h}$; (B) Effects of $200 \mu \mathrm{g} / \mathrm{ml} \mathrm{Eu}_{2} \mathrm{O}_{3}$ on HeLa cells at different times. Each column represents the mean \pm SD of six samples.-visible absorption spectra of (a) the nanoparticles and (b) pure FITC.

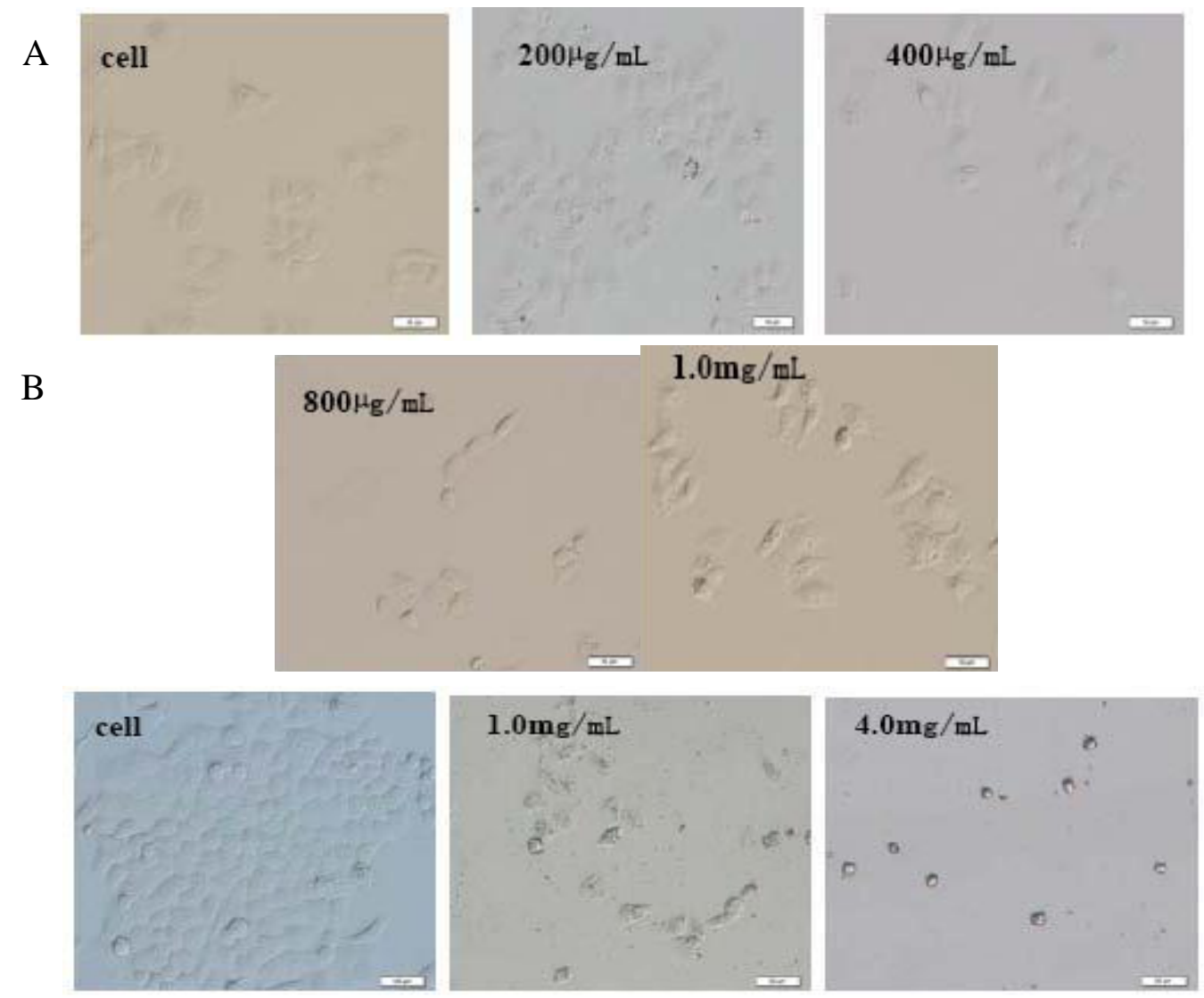

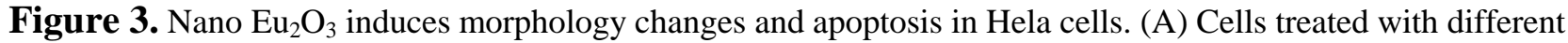
concentration of $\mathrm{Eu}_{2} \mathrm{O}_{3}$ cells for $24 \mathrm{~h}$; (B) Cells treated with different concentration of $\mathrm{Eu}_{2} \mathrm{O}_{3}$ for $28 \mathrm{~h}$. Bar, $50 \mu \mathrm{m}$. 
A

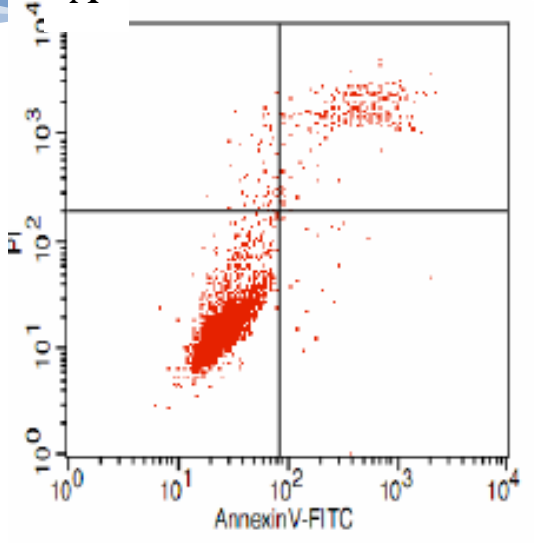

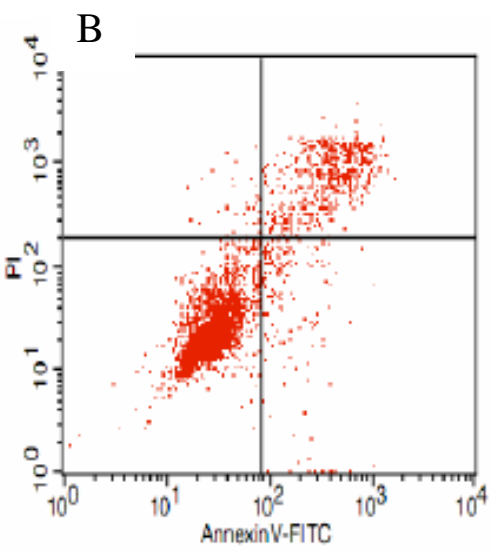

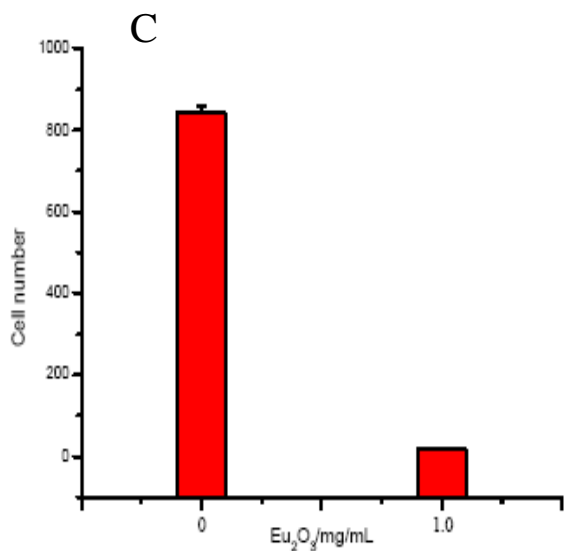

Figure 4. Apoptosis analysis. (A) Cell cultivating for $72 \mathrm{~h}$ (the control group). (B) Cells treated with $200 \mu \mathrm{g} / \mathrm{mL}$ $\mathrm{Eu}_{2} \mathrm{O}_{3}$ for $72 \mathrm{~h}$. (C) Cells treated with or without $1.0 \mathrm{mg} / \mathrm{mL}$ nano $\mathrm{Eu}_{2} \mathrm{O}_{3}$ for $28 \mathrm{~h}$. Each value represents the mean $\pm \mathrm{SD}$ of 5 determinations.
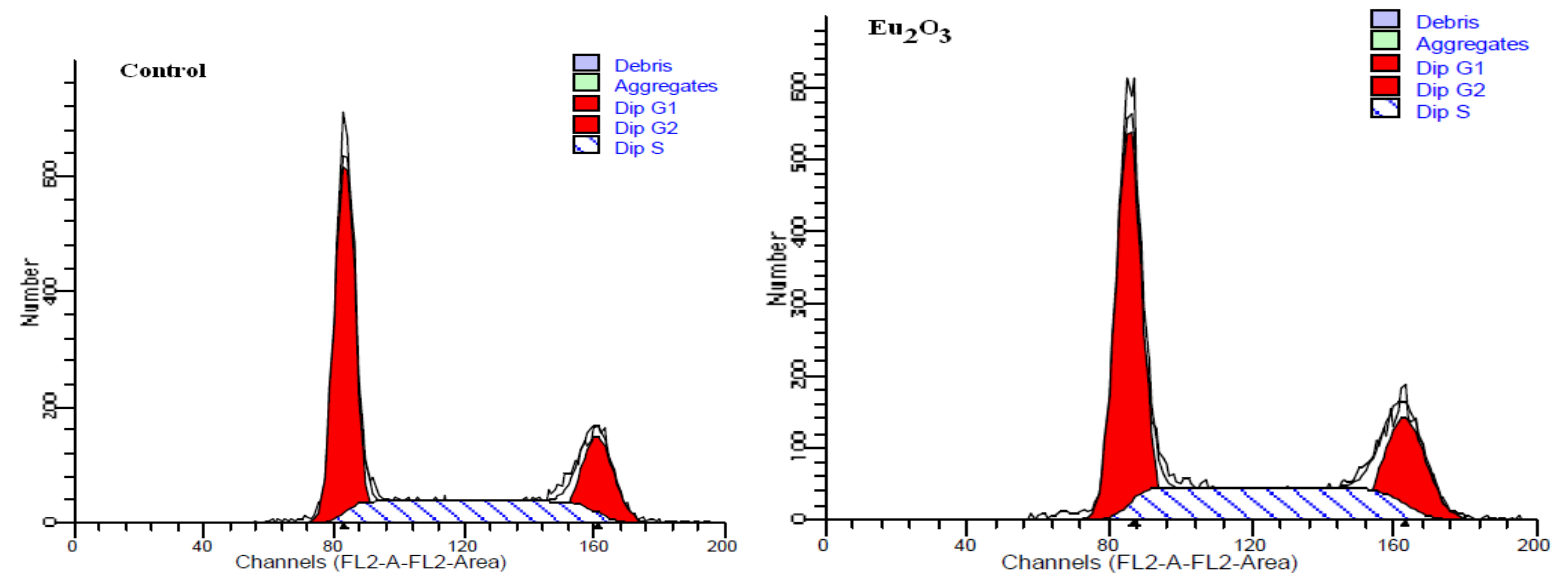

Figure 5. $200 \mu \mathrm{g} / \mathrm{mL} \mathrm{Eu}_{2} \mathrm{O}_{3}$ did not effect on cell cycle progression in Hela cells. Cell Cycle analysis by FACS: Hela cells were treated with $200 \mu \mathrm{g} / \mathrm{ml} \mathrm{Eu}_{2} \mathrm{O}_{3}$ for $72 \mathrm{~h}$. Cell cycle analysis of treated and untreated cells was performed. Data are presented as the relative fluorescence intensity of cell sub-populations in the 2-dimensional FACS profile.

Next, we examed the effects of relative high concentration of nano $\mathrm{Eu}_{2} \mathrm{O}_{3}$ on the cellular proliferation and morphologies. Initially, cells were treated with different concentration of nano $\mathrm{Eu}_{2} \mathrm{O}_{3}(200,400,800$, and $1000 \mu \mathrm{g} / \mathrm{mL}$ ) for 24 and $28 \mathrm{~h}$. Interestingly, the cell membrane was vacuolated after nano $\mathrm{Eu}_{2} \mathrm{O}_{3}$ treatment, even the cells treated with the $200 \mu \mathrm{g} / \mathrm{mL}$ nano $\mathrm{Eu}_{2} \mathrm{O}_{3}$, but there is no obvious cell number reduction in this concentration (figure 3A). On the other hand, there are obvious effects of the nano $\mathrm{Eu}_{2} \mathrm{O}_{3}$ on the cell apoptosis when the nano particles concentration is up to 1.0 $\mathrm{mg} / \mathrm{mL}$ (figure 3B).

By contrast, cells showed dramatically apoptosis treated with the concentration of 1.0 and $4.0 \mathrm{mg} / \mathrm{mL}$

$\mathrm{Eu}_{2} \mathrm{O}_{3}$ for $28 \mathrm{~h}$ (Figure 3B). Figure 4C indicated that the apoptosis rate at the concentration of $1.0 \mathrm{mg} / \mathrm{mL}$ reached $98 \%$.
The above-mentioned results indicated that the damage to the cells from the nano $\mathrm{Eu}_{2} \mathrm{O}_{3}$ particles increased obviously along with the concentration increasing. Moreover, we studied the effect of the nano $\mathrm{Eu}_{2} \mathrm{O}_{3}$ particles on the cell cycle. Figure 5 showed the expression pattern characteristics of the analysis of each cell cycle on the flow cytometry.

When the cells do not enter the fission process, they are on the position of G1 period of the cell cycle. Therefore, the quantity of G1 cells absolutely forms the highest signal peak on the flow expression pattern. In the cells of G1 period, there is a group of cells specially silent, not entering any biological features of the cellular circulation, and these cells are called the cells in G0 period. Similarly, the cells in G2 and M period have the DNA content twice as the normal cells in G1 period, and form the signal peak twice as in G1 period on the column diagram. Actually, the ratio of G2/G1 is 


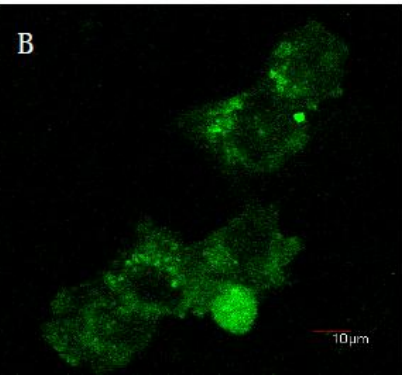

Figure 6. Alteration of $\mathrm{Ca}^{2+}$ distribution with the fluorescence indicator Flour-3/Am. (A) Cell in the control group (B) $\mathrm{Ca}^{2+}$ gathered in HeLa cells after 1.0 $\mathrm{mg} / \mathrm{mL} \mathrm{Eu}_{2} \mathrm{O}_{3}$ treatment.

always less than 2.0, maybe because the DNA-protein (chromatin) of the cells in G2 period gathers more closely or is more concentrated, there when the DNA dye is coloring, the ability of combining with the DNA locus is weakened. It is analyzed from figure 6 that after the $200 \mu \mathrm{g} / \mathrm{mL} \mathrm{Eu}_{2} \mathrm{O}_{3}$ treating the cells for $72 \mathrm{~h}$, compared with the control group, the ratio of $\mathrm{G} 1 / \mathrm{G} 0$ decreased by about $3.44 \%$, the ratio of G2/M increased by about $0.33 \%$, and the ratio to the cells in $\mathrm{S}$ period increases by about $3.11 \%$. Therefore, it is concluded that the cells treated with the $200 \mu \mathrm{g} / \mathrm{mL} \mathrm{Eu}_{2} \mathrm{O}_{3}$ had no obvious effect on the cell cycle. In this experiment, we also tried to measure the effect of high-concentration $\mathrm{Eu}_{2} \mathrm{O}_{3}$ on the cell cycle, however the highconcentration $\mathrm{Eu}_{2} \mathrm{O}_{3}(1.0 \mathrm{mg} / \mathrm{mL})$ particles covered the monolayer cells in the culture dish, influenced the detachment and collection of the cells, and it was hard to obtain adequate cell quantity to make the cellular flow experiments.

The concentration of $\mathrm{Ca}^{2+}$ in the cytoplasm must be in the strict control, and the $\mathrm{Ca}^{2+}$ stability maladjustment must cause the severe cellular damage and death. Therefore, we further checked the effect of the $\mathrm{Eu}_{2} \mathrm{O}_{3}$ on the free $\mathrm{Ca}^{2+}$ distribution in the cells. To adopt the $\mathrm{Ca}^{2+}$ fluorescence indicator flour-3/Am to measure the variation of the intra-cellular free $\mathrm{Ca}^{2+}$ level after the treatment of HeLa cells with $1.0 \mathrm{mg} / \mathrm{mL}$ nano $\mathrm{Eu}_{2} \mathrm{O}_{3}$, as figure 6 showed. The result indicated that, compared with the $\mathrm{Ca}^{2+}$ level in the cells at quiescent stage, the addition of the nano particles made obvious $\mathrm{Ca}^{2+}$ gathering in the cells, while in the control group, the $\mathrm{Ca}^{2+}$ was well distributed in the cytoplasm. The experiments showed that the introduction of the nano particles made the $\mathrm{Ca}^{2+}$ in the cells gathered and the local $\mathrm{Ca}^{2+}$ concentration obviously rose. We therefore postulated the alteration of $\mathrm{Ca}^{2+}$ distribution might lead to the $\mathrm{Ca}^{2+}$ stability maladjustment in the cells, and further cause the cell damaging and the apoptosis.

The selected nano $\mathrm{Eu}_{2} \mathrm{O}_{3}$ particle diameter is $60 \mathrm{~nm}$, while it is roughly estimated that the diameter of the nano $\mathrm{Eu}_{2} \mathrm{O}_{3}$ particle entering the cells is about $600 \mathrm{~nm}$, observed with the Laser Scanning Confocal Microscope, i.e. the diameter turns larger by about 10 times. The reason is that the nano particles are in the DMEM (10 \% FBS) suspending liquid, although dispersing them with ultrasonic wave, due to the gathering feature of the nano particle, factually, the diameter of the nano $\mathrm{Eu}_{2} \mathrm{O}_{3}$ particle in the suspending liquid we obtained is about $600 \mathrm{~nm}-1 \mu \mathrm{m}$, similar to the size of the particle entering the cells we observed. The size of the HeLa cell is $10-25 \mu \mathrm{m}$. It allows the gathered nano $\mathrm{Eu}_{2} \mathrm{O}_{3}$ entering the cells by endocytosis. In the present work, we firstly observed the nano $\mathrm{Eu}_{2} \mathrm{O}_{3}$ could enter the living HeLa cell through endocytosis. Our result showed that the cells were vacuolated with nano $\mathrm{Eu}_{2} \mathrm{O}_{3}$ treatment, even if the concentration of nano $\mathrm{Eu}_{2} \mathrm{O}_{3}$ is $200 \mu \mathrm{g} / \mathrm{mL}$. When treating the cells with the high-concentration nano $\mathrm{Eu}_{2} \mathrm{O}_{3}$, there was obvious apoptosis effect on the cells. While quantitatively analyzed the effects of the low-concentration nano particles to the apoptosis and the cell cycle specificity with the flow cytometry, the result showed that the low-concentration nano $\mathrm{Eu}_{2} \mathrm{O}_{3}(<1.0 \mathrm{mg} / \mathrm{mL})$ had no obvious biological effects, and the high-concentration nano $\mathrm{Eu}_{2} \mathrm{O}_{3}(\geqslant 1.0 \mathrm{mg} / \mathrm{mL})$ had obvious toxic effects to the cells. Because the nano $\mathrm{Eu}_{2} \mathrm{O}_{3}$ cannot enter the cell through receptor-mediated, it may enter the cell through the nonspecific pinocytosis. During the serial layer scanning the cell with the Laser Scanning Confocal Microscope, it cannot found that the expected nano $\mathrm{Eu}_{2} \mathrm{O}_{3}$ particles gather on the inner wall of the cell membrane; but found that they gathered on the outer membrane of nucleolus, and meanwhile some part $\mathrm{Eu}_{2} \mathrm{O}_{3}$ particles was suspending randomly in the cytoplasm.

The nano $\mathrm{Eu}_{2} \mathrm{O}_{3}$ might be packed by the endosome, and this kind of existence and distribution status reduced their interference to the cell pathway and the cellular organ, which might be the reason that the lowconcentration nano $\mathrm{Eu}_{2} \mathrm{O}_{3}$ has no obvious effect to the cellular biological activity. At the high concentration, after adopting the $\mathrm{Ca}^{2+}$ fluorescence indicator flour$3 / \mathrm{Am}$ to measure the effect of with the $1.0 \mathrm{mg} / \mathrm{mL}$ $\mathrm{Eu}_{2} \mathrm{O}_{3}$, the free $\mathrm{Ca}^{2+}$ level in the HeLa cells varied. The result indicated that, compared with the $\mathrm{Ca}^{2+}$ level in the cells at quiescent stage, the addition of the nano particles result in the $\mathrm{Ca}^{2+}$ in the cells gather, leading to the obvious rise of the local concentration. The inhibition of the high-concentration $\mathrm{Eu}_{2} \mathrm{O}_{3}$ to the cell proliferation maybe through the down-regulation of the $\mathrm{Ca}^{2+}$-relying protein kinase $\mathrm{C}$ and the calmodulin, to inhibit the cancer cell growth, and its apoptosis mechanism still needs the further investigation.

\section{Acknowledgements}

This work was financially supported by the State Natural Science Foundation (Grant No.: 20637010), the Natural Science Foundation of Shanxi Province (Grant 
No.: 2009011012-3), and the Natural Science Youth Foundation of Shanxi Province (Grant No.: 20051006).

\section{References}

1. Switzer ME. The lanthanide ions as probes of calcium ion binding sites in biological systems. Sci Prog. 1978; 65:19-30.

2. Das T, Sharma A, Talukder G., Effects of lanthanum in cellular systems. Biol. Trace Elem. Res. 1988;18: 201-228. doi:10.1007/BF02917504.

3. Wang K, Cheng Y, Yang XG.. Cell responses to lanthanides and potential pharmacological actions of lan-thanides. Metal Ions Biol. Syst. 2003; 40: 707-751.

4. Kramsch DM, Aspen AJ, Rozler LJ. Atherosclerosis: Prevention by agents not affecting abnormal levels of blood lipids. Science, 1981; 213:1511-1512. doi:10.1126/ science.6792706.

5. Zhang Y, Fu L, Li J, Yang X, Yang X, Wang K. Gadolinium promoted proliferation and enhanced survival in human cervical carcinoma cells. Biometals 2009; 22(3): 511-519. doi:10.1007/s10534-009-9208-5.

6. Niemeyer CM, Nanoparticles, Proteins, and Nucleic Acids: Biotechnology Meets Materials Science. Angew. Chem. Int. Ed. 2001; 40: 4128-4158. doi:10.1002/1521-3773.

7. Sahoo SK, Labhasetwar V, Nanotech approaches to drug delivery and imaging. Drug Discov. Today 2003; 8:11121120. doi:10.1016/S1359-6446(03)02903-9.
8. Alivisatos $\mathrm{P}$, The use of nanocrystals in biological detection. Nature Biotech. 2004; 22: 47-52. doi:10.1038/nbt927.

9. Ferrari M. Cancer nanotechnology: opportunities and challenges. Nature Rev. Cancer 2005; 5:161-171. doi:10.10 $38 / \mathrm{nrc1} 1566$

10. Sokolova V, Epple M. Inorganic Nanoparticles as Carriers of Nucleic Acids into Cells. Angew. Chem. Int. Ed. 2008; 47: 1382-1395. doi:10.1002/anie.200703039.

11. Yolanda Castro, Beatriz Julian edric Boissi ere1, Bruno Viana1, Heinz Amenitsch, David Grosso, C ement Sanchez1. High spatially resolved morphological, structural and spectroscopical studies on copper oxide nanocrystals. Nanotechnology, 2007; 18: 1-6.

Received 12 January, 2010; accepted 18 February, 2010; published online 5 March, 2010.

Copyright: (c) $2010 \mathrm{Y}$. Li et al. This is an open-access article distributed under the terms of the Creative Commons Attribution License, which permits unrestricted use, distribution, and reproduction in any medium, provided the original author and source are credited. 